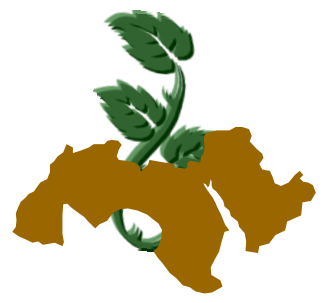

\title{
EFFECT OF CROP ROTATIONS AND NITROGEN FERTILIZATION ON YIELD, YIELD COMPONENTS AND ASSOCIATED WEEDS IN COTTON
}

\author{
Toaima1, S.E.A. \\ 1- Field Crops Research Institute, Crop Intensification Research Dep., ARC, Giza, Egypt
}

Keywords: Cotton; Crop rotations; Nitrogen fertilization; Seed cotton yield; Weeds

\begin{abstract}
This study was conducted at Sids Experimental Research Station, Beni Suief Governorate, starting from year 2000 to study the effect of rotation duration (every year, 2- year rotation and 3- year rotation) and nitrogen fertilizer rates; 45, 60 and $75 \mathrm{~kg}$ $\mathrm{N} /$ fed on growth, yield components and yield of cotton, as well as associated weeds. A split plot design was used with four replicates. The data indicated that crop rotation had significant effect on plant height, number of fruiting branches/ plant, number of open bolls, seed cotton yield/ plant and seed cotton yield/ fed. Seed cotton yield/ fed was increased by 10.99 and $23.62 \%$ when 2year and 3-year rotations were applied, compared to 1-year rotation (average of both seasons). Increasing $\mathrm{N}$ - fertilization up to $60 \mathrm{~kg} \mathrm{~N} /$ fed caused significant increases in all studied traits. The best estimate of yield $(\mathrm{Y})$ plotted against $\mathrm{N}$ rate $(\mathrm{X})$ for annually rotated cotton was the linear equation of $\mathrm{Y}=2.44+0.074 \mathrm{x}\left(\mathrm{R}^{2}=0.81\right)$. Two years rotation showed a quadratic association with increasing the $\mathrm{N}$ rate, $\mathrm{R}^{2}=0.86$ and 0.88 , respectively. The highest values of total fresh weeds were 2.85 and 2.60 $\mathrm{kg} / \mathrm{m}^{2}$ (broad and grassy weeds) when 1 -year rotation was applied, while the lowest values were 1.50 and $1.35 \mathrm{~kg} / \mathrm{m}^{2}$ when 3 -year rotation was applied in the first and second season, respectively.
\end{abstract}

\section{INTRODUCTION}

Cotton is still playing an essential role in the national economy of Egypt. Crop rotation is one of the most important parameters influencing cotton yield productivity. Several factors have affected cotton yield such as fertilization, tillage and soil type. Oleszek and Jurzysta (1987) reported that repeating growing alfalfa plants for long term may be responsible for extracted allelopathic components from alfalfa roots that accumulated and leached into soil, hence reduced the final yield. Crookston and Kurle (1989) stated that alternating one crop with another may result in beneficial differences in soil moisture conditions, physical properties of soil, weeds, insects, diseases and plant nutrition. They added also that the residues of alternates crops had a stimulatory effect on one another under rotation system and thus may explain the increase in seed- cotton yield/ fed when cotton was grown in 3-years rotation. Badr, et al (1993) revealed that crop rotation significantly affected plant height, number of fruiting branches, total bolls, open bolls and un-open bolls/ plant, boll weight, seed cotton yield/ plant, lint weight/ plant and cotton yield/ fed. The highest seed cotton yield/ fed was obtained when cotton was grown in 3- year rotation, while those grown in 2- years rotation and in continuous monoculture ranked second and third, respectively. Abou- Kresha (1998) showed that the three years rotation gave the best cotton yield/ plant and per feddan, compared to one or two years rotation. 
Nitrogen plays a major role in determining the expression of a wide range of cotton plant variables including number of fruiting branches/ plant, total bolls number/ plant and seed yield/ plant and per feddan. Several investigators studied the effect of nitrogen fertilizer on growth and yield of cotton under Egyptian conditions. Sawan et al (1991) found that dry matter yield, $\mathrm{N}$ uptake/ plant, number of open bolls/ plant, boll weight, seed index, seed cotton yield per hectare increased with increasing $\mathrm{N}$ rate. El-Kalla et al (1994) and Makram and Abdel-Malak (1997) reported that increasing nitrogen level from 60 to $90 \mathrm{~kg} \mathrm{~N} /$ fed. led to increases in plant height, number of fruiting branches and number of open bolls/ plant as well as seed cotton yield per plant and per feddan. Hamissa et al (2000) and Farghaly and Zohry (2002) showed that cotton characters increased by increasing N levels up to $75 \mathrm{~kg} \mathrm{~N} /$ fed.

Results from other countries recorded the same trend. Boquet et al (1993) in USA, found that the total harvestable bolls/ plant and cotton yield were improved by application of $150 \mathrm{~kg} \mathrm{~N} /$ hectare. Damo et al (1998) and Avile and Aragon (1998) reported that seed cotton yield and other traits such as plant height, weight of boll and number of bolls/ plant were significantly affected by increasing $\mathrm{N}$ up to $100 \mathrm{~kg} \mathrm{~N} /$ ha. Baumhardt and Robert (1999) reported that total lint production of cotton was higher by $200 \mathrm{~kg} /$ ha when used 3- year rotation system, compared with the average of annual lint yield/ ha

Cotton plants suffer from some weed invasion especially Xanthium spinosum L. (broad leaved weed) and Echinochloa colonum (L.) Link, Eleusine indica (L.), Gaertn and Cuperus longus $L$. (grassy weeds) causing great yield reduction. Integrated weed management is needed for solving this problem through testing various options for controlling weeds, such as cultural practices, crop rotations and the use of current recommended herbicides. Zohry (2005) indicated that weeds weight in crops that grown after legume crop were lower than weeds weight produced after wheat.

This investigation aimed to study the effect of crop rotations and $\mathrm{N}$ fertilizer rates on growth, seed cotton yield, yield components and associated weeds.

\section{MATERIALS AND METHODS}

In 2001/ 2002 season three crop rotations experiments have been started at Sids Agric. Res. Stn. Beni Suief Governorate. The first one was 1-year rotation (clover/ cotton), the second was 2-year rotation (clover/ cotton-wheat/maize) and the third was 3-year rotation (clover/ cottonwheat/maize- faba bean/ maize), (Table 1). Total fresh weight of weeds associated with cotton were estimated. The present study was conducted during 2005 and 2006. A split plot design with four replications was used. The three crop rotations were arranged in the main plots. While sub- plots were devoted to the three nitrogen levels, i.e. 45 , 60 and $75 \mathrm{~kg} \mathrm{~N} / \mathrm{fed}$. Sub-plots were $5 \times 3.6 \mathrm{~m}^{2}$, comprising 6 ridges $60 \mathrm{~cm}$ wide and $5 \mathrm{~m}$ length.

Cotton was sown on $17^{\text {th }}$ and $21^{\text {st }}$ of March in the first and second seasons, respectively. Cotton (cv. Giza 80) was sown at a distance of $20 \mathrm{~cm}$ between hills and thinned at 2 plants/ hill on one side of the ridge.

Nitrogen fertilizer was divided into two equal doses applied at the first and second irrigations, in the form of ammonium nitrate $33.5 \% \mathrm{~N}$. Other cultural practices were applied as recommended. Cotton plants were harvested on $20^{\text {th }}$ and $25^{\text {th }}$ September in the first and second seasons, respectively. Ten guarded plants were chosen at random from each sub-plot to determine cotton plant height $(\mathrm{cm})$, number of fruiting branches/ plant, number of bolls/ plant, boll weight (g), seed cotton weight of ten bolls ( $\mathrm{g}$ ), seed weight of ten bolls (g), lint weight of ten bolls (g) and seed cotton yield/ plant (g). While seed cotton yield/ fed. was estimated on the whole plot basis and converted to unit scale of kentar. $($ Kentar $=157.5 \mathrm{~kg})$.

Representative soil samples from the experimental site were taken for chemical analysis (Table 2) before starting the experiment 1999/2000 and after harvesting summer crops during 2005 and 2006 seasons, according to Black (1965).

Simple and multiple correlations and linear regression were used to study the nature of relationships between seed- cotton yield and crop rotations and nitrogen fertilizer level as follows:

1-Simple correlation: A matrix correlation coefficients between seed cotton yield and crop rotations $\left(\mathrm{X}_{1}\right)$ and nitrogen fertilizer rate $\left(\mathrm{X}_{2}\right)$ were computed according to Snedecor and Cochran (1988).

2- Multiple linear regression: Multiple linear regression and multiple coefficient of determination $\left(\mathrm{R}^{2}\right)$ were estimated according to Snedecor and Cochran (1988) to evaluate the relative contribution of the studied treatments on seed- cotton yield (y) according to: 
Table 1 . The three cotton rotations types

\begin{tabular}{|c|c|c|c|c|c|c|c|c|c|}
\hline Years & \multicolumn{2}{|c|}{$2001 / 2002$} & \multicolumn{2}{|c|}{$2002 / 2003$} & \multicolumn{2}{|c|}{$2003 / 2004$} & \multicolumn{2}{|c|}{$2004 / 2005$} & $2005 / 2006$ \\
\hline \multirow{2}{*}{$\begin{array}{c}\text { Season } \\
\begin{array}{c}1-\text { year } \\
\text { rotation }\end{array}\end{array}$} & \multirow{2}{*}{$\begin{array}{l}\text { Winter } \\
\text { Clover }\end{array}$} & \multirow{2}{*}{$\frac{\text { Summer }}{\text { Cotton }}$} & \multicolumn{2}{|c|}{ Winter Summer } & \multicolumn{2}{|c|}{ Winter Summer } & \multicolumn{2}{|c|}{ Winter Summer } & Winter Summer \\
\hline & & & Clover & Cotton & Clover & Cotton & Clover & *Cotton & Clover $* *$ Cotton \\
\hline 2- year & Clover & Cotton & Wheat & Maize & Clover & Cotton & Wheat & Maize & Clover $* *$ Cotton \\
\hline rotation & Wheat & Maize & Clover & Cotton & Wheat & Maize & Clover & *Cotton & Wheat \\
\hline 3- year & Clover & Cotton & Faba bean & Maize & Wheat & Maize & Clover & *Cotton & Faba bean Maize \\
\hline rotation & Wheat & Maize & Clover & Cotton & Faba bean & Maize & Wheat & Maize & Clover $* *$ Cotton \\
\hline & Faba bea & an Maize & Wheat & Maize & Clover & Cotton & Faba bean & n Maize & Wheat \\
\hline
\end{tabular}

* First season 2005 cotton experiment

** Second season 2006 cotton experiment

Table 2. Chemical analysis of the experimental site soil

\begin{tabular}{|c|c|c|c|c|}
\hline \multirow{2}{*}{$\begin{array}{l}\text { Chemical } \\
\text { analysis }\end{array}$} & \multirow{2}{*}{$\begin{array}{c}\text { Before } \\
\text { starting the } \\
\text { crop rotation }\end{array}$} & \multicolumn{3}{|c|}{$\begin{array}{l}\text { After harvesting cotton } \\
\text { (average of } 2005 \text { and } 2006 \text { seasons) }\end{array}$} \\
\hline & & 1- year rotation & 2- year rotation & 3- year rotation \\
\hline $\mathrm{pH}(1: 2.5$, soil: water $)$ & 7.7 & 7.8 & 7.7 & 7.7 \\
\hline Ec mmohs/ cm & 0.45 & 0.47 & 0.46 & 0.46 \\
\hline Available N (ppm) & 44.6 & 50.8 & 40.5 & 42.3 \\
\hline Available P (ppm) & 9.2 & 9.4 & 9.7 & 10.3 \\
\hline Available K (ppm) & 350 & 378 & 340 & 360 \\
\hline $\mathrm{Na}$ & 4.75 & 4.80 & 4.76 & 4.70 \\
\hline $\mathrm{CaCo} 3$ & 3.62 & 3.66 & 3.61 & 3.61 \\
\hline
\end{tabular}

$Y=a+b_{1} x_{1}+b_{2} x_{2} \quad$ Where:

$\mathrm{A}=$ The intercept, (the equation constant)

$b_{1}, b_{2}=$ Partial regression coefficient for $X_{1}$ and $\mathrm{X}_{2}$, respectively.

Gross profit. Economic and cereal units, were evaluated. Cereal Units (CUS) procedure were calculated according to Roger (1985) and they were used as a measure of economic evaluation of the intercrops. The main and by-products of intercrops were estimated as:

100 kilograms of lint cotton $\quad=9.580$ CUS .

100 kilograms of cotton seed $=1.500$ CUS.

$$
100 \text { kilograms of clover } \quad=1.500 \text { CUS. }
$$

Gross profit was calculated as L.E. 600 / kentar of seed cotton, and L.E. 130 / ton clover according to the prices of year 2005 .

\section{RESULTS AND DISCUSSION}

\section{1- Effect of crop rotations on cotton}

Data of cotton yield and its components as affected by crop rotations are shown in Table (3). Results showed that growth traits; plant height, and number of fruiting branches/ plant were significantly affected by the rotation types in both seasons. It is evident that plant height, as well as, number of fruiting branches/ plant reached their maximum values by growing cotton in 3- year rotation. Growing cotton in 2- year rotation ranked the second, where the lowest values were obtained when cotton was grown in 1- year rotation. These results hold true in both seasons. Number of total bolls, number of closed and open bolls/ plant, as well as weight of boll were significantly affected 
Arab Univ. J. Agric. Sci., 15(2), 2007 
by crop rotations. Growing cotton in three- year rotation recorded the highest values of bolls number and weight of boll, while growing cotton in 1year rotation recorded the lowest values. Seed cotton weight, seed weight and lint weight/ 10 bolls were increased in both seasons when cotton was grown in 3- year rotation. Seed cotton yield/ plant as well as seed cotton yield/ fed were higher when cotton was grown in 3- year rotations, as compared to those grown in 1 or 2 - year rotations. The increments of seed - cotton yield/ fed grown in the 3-year rotations amounted 15.97, $34.11 \%$ and $6.02,13.13 \%$ in both seasons as compared to the 1- year rotation, respectively. These increments were quite expected since most of cotton traits were increased such as number of fruiting branches/ plant number of open bolls, lint weight and seed weight/ boll and seed cotton yield /plant. These results are in agreement with those obtained by Crookston and Kurle (1989). They revealed that alternating one crop with another may result in beneficial differences in soil moisture conditions, physical properties of soil, plant nutrition, and control of weeds, insects and diseases. They added also that the residues of alternates' crops had a stimulatory effect on one another under rotational system and thus may explain the increase in seed- cotton yield/ fed when cotton was grown in 3- year rotation.

From the previous results, the reduction in seed cotton yield when cotton was grown in 1-year rotation may be responsible for extracted allelopathic components from cotton roots that accumulated and leached into soil due to repeating growing cotton in the same area. As well as, higher absorptive capacity and higher activity of soil microorganisms of heavy soil under the experiment condition (Oleszek and Jurzysta (1987).

\section{B- Effect of $\mathbf{N}$ fertilizer rates on cotton}

Data in Table (4) indicated clearly that plant height and number of fruiting branches/ plant were significantly affected by raising nitrogen fertilizer level. The highest values for plant height were noticed when the highest rate of $\mathrm{N}$ was applied (75 $\mathrm{kg} \mathrm{N} / \mathrm{fed}$ ), whereas, the lowest value was recorded when the lowest rate was applied $(45 \mathrm{~kg} \mathrm{~N} /$ fed). In case of number of fruiting branches/ plant, it reached its maximum value when $60 \mathrm{~kg} \mathrm{~N} / \mathrm{fed}$ was applied, then decreased as the rate of nitrogen increased to $75 \mathrm{~kg}$ / fed. These results were true in both seasons. Data also indicated that, the other studied traits of cotton, i.e., yield components and yield/ fed were significantly affected by nitrogen fertilizer rates, except in case of number of closed bolls/ plant in both seasons. However, weight of seed cotton and weight of seeds/ 10 bolls were not significantly affected by nitrogen rates in the first season, and lint percentage showed also the same in the second season. The maximum values were recorded for all traits when $60 \mathrm{~kg} \mathrm{~N} /$ fed was added. On the other hand, the lowest values were obtained when $45 \mathrm{~kg} \mathrm{~N} /$ fed was added. The increments of seed cotton yield/ fed were 30.31, 17.23 $\%$ and $34.16,15.44 \%$ in both seasons when adding 60 and $75 \mathrm{~kg} \mathrm{~N} / \mathrm{fed}$, respectively as compared with the lowest dose (45 kg/ fed). Similar results were obtained by Sawan (1997), Abou Kresha (1998) and Avile and Aragon (1998). These results might be attributed to the pronounced effect of $\mathrm{N}$ on the yield components such as number of open bolls, weight of bolls and seed cotton yield/ plant.

\section{C- Effect of interaction on growth, yield and yield attributes of cotton}

The results of the interaction effects between crop rotation and $\mathrm{N}$ fertilizer rates (Table 5) on plant height revealed that plant height was increased by increasing $\mathrm{N}$ rates under the three types of crop rotation in both seasons. This increase did not reach the $5 \%$ level significance with increasing $\mathrm{N}$ rates from 60 to $75 \mathrm{~kg} \mathrm{~N} /$ feddan under 2-yr and 3 -yr rotation in the first season, but this increase reached to $5 \%$ level significance with increasing $\mathrm{N}$ level up to $75 \mathrm{~kg} \mathrm{~N} /$ fed. in the second season.

Concerning number of fruiting branches/ plant, this trait was increased by adding $\mathrm{N}$ level up to 60 $\mathrm{kg} \mathrm{N} /$ fed., then decreased at $75 \mathrm{~kg} \mathrm{~N} /$ fed., but between 60 and $75 \mathrm{~kg} \mathrm{~N} /$ fed under 1-yr rotation and 2- yr rotation did not reach to $5 \%$ significant with increasing $\mathrm{N}$ rate. On the other hand, with 3yr rotation the increase in $\mathrm{N}$ fertilizer level significantly reduced this trait in both seasons.

With respect to number of total bolls/ plant, number of closed bolls and number of open bolls/ plant, data showed that insignificant difference between adding 60 and $75 \mathrm{~kg} \mathrm{~N} /$ fed under 3-yr rotation, in the first season, but it reached $5 \%$ level significance in the second season under all types of crop rotations.

Weight of seed cotton/ 10 bolls, data revealed increases in weight of seed cotton/ 10 bolls with adding 45 and $60 \mathrm{~kg} \mathrm{~N} /$ fed, thereafter decreased were observed when $75 \mathrm{~kg} \mathrm{~N} /$ fed was added in all 
Arab Univ. J. Agric. Sci., 15(2), 2007 
types of crop rotations. Weight of seeds and weight of lint/ 10 bolls did not reach to $5 \%$ level of significance in the first season. But, in the second season data reach to $5 \%$ level of significance and responded to adding $\mathrm{N}$ fertilizer level up to 60 $\mathrm{kg} \mathrm{N} / \mathrm{fed}$, thereafter, decreased were observed when $75 \mathrm{~kg} \mathrm{~N} /$ was added. Lint percentage did not reach to $5 \%$ level of significance in the first season, but it was reached to $5 \%$ level of significance in the second season. Results indicated that 3- year rotation recorded the highest values, whereas 1year rotation recorded the lowest values.

Seed cotton yield/ plant and per feddan increased with increasing $\mathrm{N}$ rate up to $60 \mathrm{~kg} \mathrm{~N} / \mathrm{fed}$, thereafter, decreases were observed when adding $75 \mathrm{~kg} \mathrm{~N} / \mathrm{fed}$, furthermore, the statistical analysis evidenced significant differences among the treatments in the first season, but, failed to show the $5 \%$ level of significance in the second season in case of seed cotton yield/ plant. On the other hand, the course of significance reversed in case of seed cotton yield/ fed.

Results were significantly higher in both 2-yr and 3-yr rotation by 36.22 and $20.00 \%$, respectively in the first season and by 31.58 and 32.87 $\%$, respectively in the second season, when $\mathrm{N}$ fertilizer was increased to $60 \mathrm{~kg}$ than $45 \mathrm{~kg} \mathrm{~N} / \mathrm{fed}$ dan. On the other hand, the reduction in seed cotton yield/ fed due to adding $75 \mathrm{~kg} \mathrm{~N} / \mathrm{fed}$, compared to $60 \mathrm{~kg} \mathrm{~N} /$ fed was 36.22 and $20.00 \%$ under $2 \mathrm{yr}$ and 3-yr rotation, respectively and 31.58 and $2.35 \%$ in the second season. These results are coincided with those obtained by Abou- Kresha (1998).

From the double interaction effects between crop rotation and $\mathrm{N}$ fertilizer rates on seed cotton yield/ fed Table 5. It could be concluded that the highest seed cotton yield/ fed was produced when cotton plants grown under 3- yr rotation and received $60 \mathrm{~kg} \mathrm{~N} / \mathrm{fed}$, this was true in the two seasons. While the lowest seed cotton yield/ fed was obtained when cotton plants grown under 1-yr rotation and received $45 \mathrm{~kg} \mathrm{~N} /$ feddan.

\section{D- Effect of relationship between crop rotations and nitrogen fertilizer rates on seed cotton yield/ fed}

Simple correlation coefficients for crop rotation and nitrogen fertilizer rate on seed cotton yield/ fed are presented in Table (6) and Figure (1). The simple correlation coefficient between seed- cotton yield and crop rotation was 0.97 and 0.92 in the first and second seasons, respectively, suggesting strong association between yield and crop rotation. The correlation coefficients between seed- cotton yield and $\mathrm{N}$ - levels were 0.96 and 0.98 in both seasons, respectively, indicating a strong association between yield and $\mathrm{N}$ level. These results clearly indicate that both crop rotation and nitrogen fertilizer had high correlation coefficient with seed-cotton yield.

Table 6. Matrix of simple correlation between seed-cotton yield and Studied factors

\begin{tabular}{|ccc|}
\hline Season & X1 & X2 \\
\hline $\mathbf{1}^{\text {st }}$ & 0.97 & 0.96 \\
2 $^{\text {nd }}$ & 0.92 & 0.98 \\
\hline
\end{tabular}

The best estimate of seed cotton yield/ fed (Y) plotted against $\mathrm{N}$ rate $(\mathrm{x})$ was provided by the linear equation $\mathbf{Y}=\mathbf{2 . 4 4}+\mathbf{0 . 0 7 4} \times\left(\mathbf{R}^{\mathbf{2}}=\mathbf{8 1}\right)$ for seed cotton yield growing 1 - year rotation. Therefore, results showed that sufficient fertilizer $\mathrm{N}$ of $75 \mathrm{~kg} /$ fed is enough comparing to 2- year and 3- year rotation systems (Fig. 1).

In 2- year rotation, the best estimate of yield for varying $\mathrm{N}$ rate was the quadratic equation $Y=-3.217+0.527 \times-0.007 \times 2\left(R^{2}=86\right)$.

In 3-year rotation, multi regression analysis showed that the response of seed cotton yield /fed to $\mathrm{N}$ fertilizer was quadratic $\mathrm{Y}=\mathbf{4 . 5 6 0}+\mathbf{0 . 6 8 2} \mathrm{x}-$ $0.065 x^{2}\left(R^{2}=0.90\right)$.

\section{E- Effect of crop rotations on weeds}

Data in Table (7) showed the effect of crop rotations on weight of total fresh weeds. Data indicated that the best sequence for weed control and seed cotton yield/ fed was recorded from 3-years rotation when faba bean/ maize preceded cotton. It gave $42.64,43.43 \%$ of the control on broad leaved weeds (Xanthinum spinosum L.) and 56.57, 57.65 $\%$ on grassy weeds (1-Echinochloa colonum (L.), 2-Eleusine indica (L.) Gaerth and Cyperus longus $L$.) as fresh weight in both seasons, respectively, compared to 1-year rotation.

Concerning the 2-years rotation; wheat/corn preceded clover/ cotton caused the second total fresh weeds control and cotton-seed yield/ fed. The results were $31.49,19.71 \%$ control of broad leaved weeds and $32.78,46.47 \%$ control of grassy weeds in the first and second seasons, respectively, compared to 1-year rotation. 
Fig. 1. Yield as a relation between crop rotation and total $\mathrm{N}$ fertilizer over two seasons

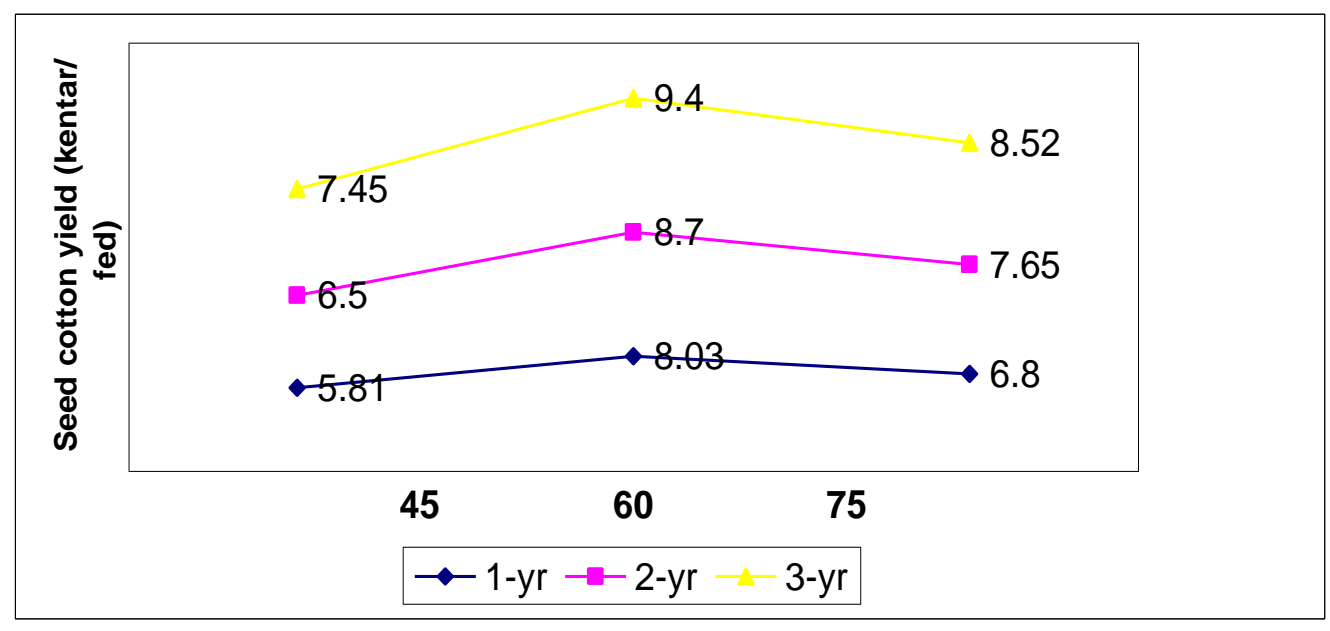

Table 7. Total fresh weight of weeds as affected by crop rotations in 2005 and 2006 seasons

\begin{tabular}{|lcccccc|}
\hline \multicolumn{1}{|c}{ Season } & \multicolumn{3}{c}{ 2005 season } & \multicolumn{3}{c|}{ 2006 season } \\
\hline $\begin{array}{l}\text { Crop } \\
\text { Rotation }\end{array}$ & $\begin{array}{r}\text { Broad } \\
\text { leaves } \\
\left(\mathrm{g} / \mathrm{m}^{2}\right)\end{array}$ & $\begin{array}{c}\text { Grass } \\
\text { Leaves } \\
\left(\mathrm{g} / \mathrm{m}^{2}\right)\end{array}$ & $\begin{array}{c}\text { Total } \\
\left(\mathrm{g} / \mathrm{m}^{2}\right)\end{array}$ & $\begin{array}{c}\text { Broad } \\
\text { Leaves } \\
\left(\mathrm{g} / \mathrm{m}^{2}\right)\end{array}$ & $\begin{array}{c}\text { Grass } \\
\text { leaves } \\
\left(\mathrm{m}^{2}\right)\end{array}$ & $\begin{array}{c}\text { Total } \\
\left(\mathrm{g} / \mathrm{m}^{2}\right)\end{array}$ \\
\hline $\begin{array}{l}\text { 1- yr rotation } \\
\text { 2- yr rotation }\end{array}$ & 1883 & 967 & 2850 & 1750 & 850 & 2600 \\
3- yr rotation & 1290 & 650 & 1940 & 1405 & 455 & 1850 \\
\hline L.S.D at 0.05 & 1080 & 420 & 1500 & 990 & 360 & 1350 \\
\hline
\end{tabular}

These results indicated that the choice of the kind of crop plants to be included in a crop rotation sequence is crucial to gave high competition with weeds. Legume crop which included in 3year rotation (faba bean/ maize) trimmed down total fresh weeds due to competition, as well as allelopathic residues that exudates from faba bean roots and diminished weed growth Zohry (2005).

It could be concluded that using 3-year crop rotation for cotton led to increase seed cotton yield/fed and reduced total fresh weight of weeds, compared to 1-year or 2-year rotation, further 60 $\mathrm{kg} \mathrm{N} /$ fed is enough to produce the highest yield.

\section{Cereal units economic and gross profit}

Data in Table (8) show the differences in cereal units/ feddan among the studied traits on crop rotation systems. Results indicate that the highest value of Cereal Units (CUS) was appeared by cotton plus clover when the 3- year rotation was applied in both seasons. Whereas, the lowest value was observed in 1- year rotation.

The gross profit in L.E. for cotton and clover are also shown in Table (8). These results are in accordance with those obtained by Abou- Kresha (1998). 
Table 8. Net yield of cotton and clover in form of cereal units (CUS) and gross profit/ fed in Egyptian pound as affected by crop rotation through 2005 and 2006 seasons

\begin{tabular}{|c|c|c|c|c|c|c|c|c|}
\hline \multirow{2}{*}{$\begin{array}{c}\text { Crop } \\
\text { rotation }\end{array}$} & \multirow{2}{*}{$\begin{array}{l}\text { Cropping } \\
\text { system }\end{array}$} & \multicolumn{4}{|c|}{ Cereal units of actual yield } & \multicolumn{3}{|c|}{ Gross profits (L.E.) } \\
\hline & & $\begin{array}{c}\text { Main } \\
\text { Production } \\
\text { Lint cotton } \\
\text { / fed }\end{array}$ & $\begin{array}{l}\text { By product } \\
\text { (cotton } \\
\text { seeds)/ fed }\end{array}$ & Beseem & $\begin{array}{l}\text { Total / } \\
\text { fed }\end{array}$ & Cotton & Berseem & Total/ fed \\
\hline \multicolumn{9}{|c|}{2005 season } \\
\hline 1-year & $\begin{array}{l}\text { Cotton }+ \\
\text { Berseem }\end{array}$ & 37.39 & 9.38 & 25.65 & 72.46 & 3870 & 2382.25 & 6252.25 \\
\hline 2- year & $\begin{array}{l}\text { Cotton + } \\
\text { Berseem }\end{array}$ & 42.40 & 11.03 & 28.59 & 82.02 & 4488 & 2654.60 & 7142.60 \\
\hline 3- year & $\begin{array}{l}\text { Cotton + } \\
\text { Berseem }\end{array}$ & 48.96 & 12.77 & 33.08 & 9481 & 5190 & 3071.90 & 8261.90 \\
\hline \multicolumn{9}{|c|}{2006 season } \\
\hline 1-year & $\begin{array}{l}\text { Cotton + } \\
\text { Berseem }\end{array}$ & 39.03 & 11.16 & 25.37 & 75.56 & 4386 & 2355.60 & 6741.60 \\
\hline 2- year & $\begin{array}{l}\text { Cotton + } \\
\text { Berseem }\end{array}$ & 42.20 & 11.70 & 27.90 & 81.80 & 4650 & 2590.90 & 7240.90 \\
\hline 3- year & $\begin{array}{l}\text { Cotton + } \\
\text { Berseem }\end{array}$ & 46.84 & 12.20 & 32.39 & 91.43 & 4962 & 3006.90 & 7968.90 \\
\hline
\end{tabular}

\section{REFERENCES}

Abou-Kresha, M.A. (1998). Contribution of intercropping in crop rotation to cotton traits and yield. J. Agric. Sci. Mansoura Univ., 23(9): 3591-3600.

Avile, E.M. and M.L. Aragon (1998). Nitrogen fertilization of promising cotton varieties in llocos region. Philipin. J. Crop Sci. 23(1): 26-32.

Badr, S.K; A.M. Aly and M.N. Sherif (1993). Studies on crop rotation systems. 1- Effect of crop rotation and planting dates on growth, yield, yield components and some fiber properties of Egyptian cotton. Egypt J. Appl. Sci. 8 (12): 1150-1164.

Baumhardt, R.L. and Robert J. Lascano (1999). Integrated soil and crop management. Agric. J. 91: 922-927.

Black, C.A. (1965). (ed) Methods of Soil Analysis. Amer. Soc. Agron., Madison, Wisc. USA.

Boquet, D.J.; E.B. Moser and G.A. Breitenbek (1993). Studies on crop rotation. 1- Effect of crop rotation and planting dates on growth, yield and yield components of cotton. J. Crop Sci., 8(12): 1150-1164.

Crookston, R.R. and J.E. Kurle (1989). Corn residue effect on the yield of corn and soybean grown in rotation. Agron. J. 82(1): 229-232.
Damo, C.B.; E.D. Orpia and J.F. Catedrel (1998). Productivity of cotton and soybean intercropping at varying $\mathrm{N}$ levels. Philippine. J. Crop Sci. 23(1): 25-30.

El-Kalla, S.E.; A.T. El-Kassaby; A.A. Leilah; M.H. Ghonema and M.M. Ismail (1994). Effect of sowing dates, population and distribution of plants and nitrogen fertilizer levels on growth and yield of Egyptian cotton. Proc. $6^{\text {th }}$ Conf. Agron., Al-Azhar Univ., Cairo, Egypt, 1(1): 95-108.

Farghaly, B.S. and A.A. Zohry (2002). Effect of preceding crops in three- year crop rotations and $\mathrm{N}$ rates on yield and yield components of Egyptian cotton. Egypt. J. Agric. Res. 80(1): 293-307.

Hamissa, A.M.; K.A. Ziadah and M.F. ElMasry (2000). Response of cotton to bio- fertilizer and nitrogen fertilization. Minufiya J. Agric. Res,. 25(2): 371-388.

Makram, E.A. and K.K. Abdel-Malak (1997). The proper nitrogen rate for Giza 83 cotton cultivar preceded by faba bean in Upper Egypt. ArabUniversities. J. Agric. Sci. 5(2): 242-250.

Oleszek, W. and M. Jurzysta (1987). The allelopathic potential of alfalfa root medicagenic and glycosides and their fate in soil environments. Plant and Soil, 98: 67-80.

Roger, G.P. (1985). Design and Analysis of Experiments. Marcel Dekker, Inc., New York. 
Sawan, Z.M.; M.H. Mahmoud and D.A Momtaz (1991). Influence of nitrogen fertilization and foliar application of plant growth retardants on qualitative properties of Egyptian cotton (Giza 75). J. Agric. and Food Chemistry (U.S.A.) 25(1): 3331-3336.

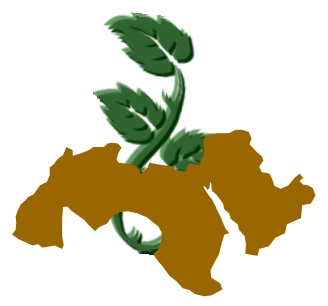

Snedecor, G.W. and W.G. Cochran (1988). Statistical Method, 7hㅡ Ed., Iowa State Univ., Press Ames, Iowa, U.S.A.

Zohry, A.A. (2005). Effect of preceding winter crops and intercropping on yield, yield components and associated weeds in maize. Annals. Agric. Sci., Moshtohor, 43(1): 139-148.

$$
\begin{aligned}
& \text { مجلة اتحاد الجامعات العربية }
\end{aligned}
$$

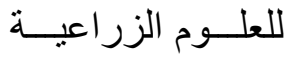

$$
\begin{aligned}
& \text { جامعة عين شمس ، مجس القاهـرة }
\end{aligned}
$$

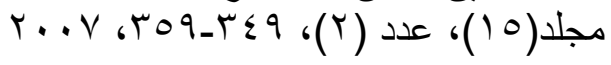

\title{
تأثير الاورات الزراعية والتسميد التتروجينى على حا صل القطن ومكوناتة والحشائش المصاحبة لة
}

\author{
صلاح السيد عطية طعيمة' \\ 1 ـ معهد بحوث المحاصيل الحقلية_ قسم بحوث التكثيف المحصولى ـ مركز البحوث الزراعية ـ الجيزة ـ مصر
}

- كان للدورات الزراعية تأثثر معنوى على ارتفاع

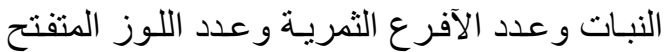

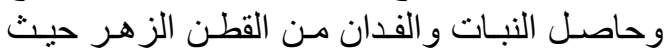

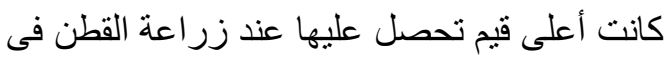

$$
\text { دورة ثلاثية. }
$$

- زاد حاصل القطن المنزر ع بنظـام الدورة الزر اعيـة

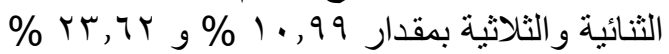

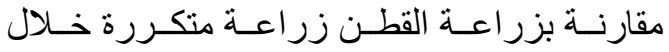

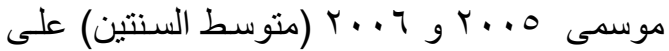

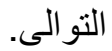

- أدى زيادة التسميد النتروجينى حتى • 7 كجم / فدان الى زيادة فى جميع الصفات التى تم در استها.

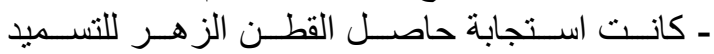

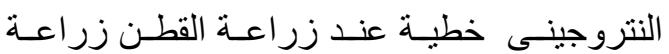

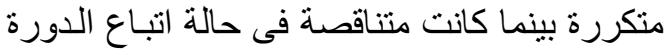
الثنائية و الثلاثية.

كما أظهرت النتائج أن أعلى وزن للحشــائش الكليـة

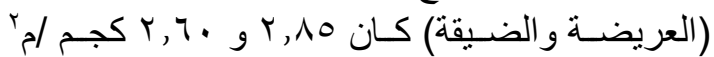

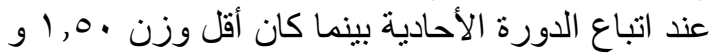

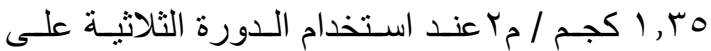

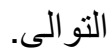

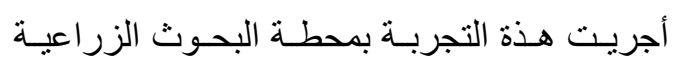

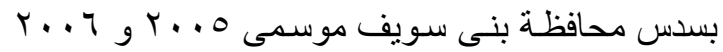

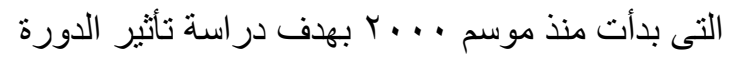

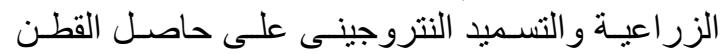

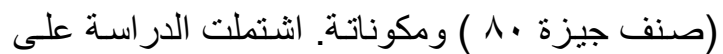
تقييم ثلاثنة دور ات زر اعية مختلفة وهي: اعهي:

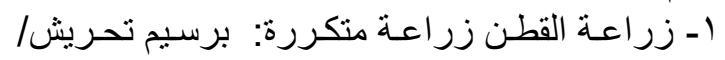
قطن

r- زر اعـة القطـن فـى دورة ثنائيـة: برسـيم تحـريشا

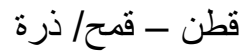

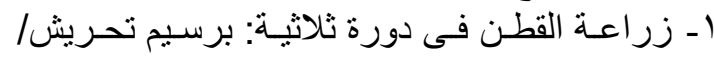

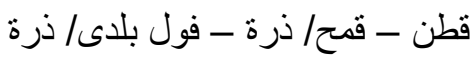

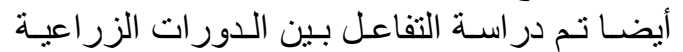

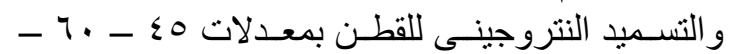

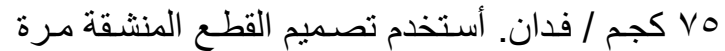

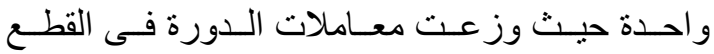

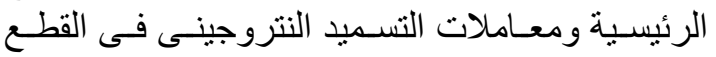
الثقية فى أربع مكرر ات.

وتتلخص أهم التتائج المتحصل عليما فيما يلى

$$
\text { تحكيم: أ.دـنوكل يونس رزق أ.د أحمد سعيد كامل }
$$

